\title{
地震観測波形とシミュレーション波形の適合度評価
}

Frequency domain error の改良と V \& Vへの適用

\section{THE GOODNESS-OF-FIT BETWEEN OBSERVED AND SIMULATED WAVES}

Modification of the frequency domain error and application to verification and validation

鈴木文乃*1, 加藤 研一 ${ }^{* 2}$, 渡辺哲史 ${ }^{* 3}$

Fumino SUZUKI, Kenichi KATO and Tetsushi WATANABE

\begin{abstract}
Verification and validation (VV) are important in seismic wave simulations. To objectively perform VV, indexes to quantitatively evaluate the goodness-of-fit (GOF) between observed and simulated waves is needed. In this study, we proposed GOF indexes considering both amplitude and phase of waveforms. The indexes wereoriginally derived from the frequency domain error (FDE) proposed by Dragovich and Lepage (2009). Wemodified FDE to expand finitefrequency bands. Wealso newly proposed GOF of envelope of waveform based on the similar concept of FDE. We applied the proposed indexes to VV of benchmark tests and strong motion simulations.
\end{abstract}

Keywords : Goodness-of-fit, Frequency domain error, Ground motion simulations, Waveform, Verification \& Validation GOF，適合度評価，FDE，地震動シミュレーション，波形，検証と妥当性確認

1. はじめに

地震動シミュレーションには、意図した条件で正しく計算がなさ れているかを検証するVerification と、観測記録との比較により物理 モデルの妥当性を確認するValidation の 2 つの意味がある。ベンチ マークテスト等による計算コードの確認例えば 1),21,31 は前者に、断層モ デル等による観測記録のシミュレーション例えば 4), 5) は後者に相当す る。一般にシミュレーション結果の Verification や Validation の判断 は、計算者の主観による場合が多い。それを客観的に行うためには、 適合度 GOF (Goodness of Fit)を定量的に評価する指標が必要となる。

GOF指標は、評価対象に応じて多様な指標が提案されている。既 往研究におけるGOF指標の特徵をTablelに示す。A nderson (2004) (1) $^{6}$ 、 PGA どの波形の最大值や応答スペクトル、フーリエ振幅スペクト ルなど10項目を対象にGOF指標を提案しており、その值に応じて poor、fair、good、excellentのランクを設定している。Bielak et al. $(2010)^{71}$ は、有限差分法と有限要素法による地震動シミュレーション に対して、A nderson ${ }^{6)}$ の10項目を用いて手法間のV erificationを多面的 に行っている。Olsen and M ayhew (2010)9)の指標は、評価対象は A nderson ${ }^{6)}$ と概社同じだが、誤差が小さい場合の感度がA nderson ${ }^{6)}$ り高い関数形であり、5段階のランクが設定されている。Dhakal and Y amanaka (2012) $)^{11}$ は、3次元地盤モデルを用いた地震動シミュレーシ ヨンと観測記録に対して、Olsen and M ayhew ${ }^{9)} の$ 指標を用いて V alidationを行い、地盤モデルの妥当性を検討している。D reger etal. $(2015)^{12)}$ は、応答スペクトル(RotD50 PSA)を評価する指標CGOF (combined goodness-of-fit)を提案している。各周期での適合度と周期 帯域での平均的な適合度の両者を考慮する指標であり、值に応じて
Within Threshold、Potential Issues、Ploblematicのランクを設定してい る。CGOFはSouthern California E arthquake Centerの広帯域地震動評価

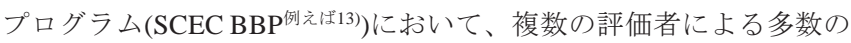
地震動評価結果のV alidationに用いる指標の一つである。

上述の3つの既往研究6), 9), 12) におけるGOF指標は、いずれも最大值、 フーリエ振幅や応答スペクトルなど、主に地震動の振幅を測る指標 である。振幅だけではなく、位相も評価する指標として次の2つが挙 げられる。1つ目として、K risteková et al. $(2006,2009)^{15), 16)}$ は、連続 ウェーブレット変換の振幅と位相を用いたGOF指標 timefrequency(TF) misfitを提案している。TF misfitは時間-周波数領域に おける適合度を評価し、A nderson ${ }^{6)}$ と同じpoor〜excellentのランクが

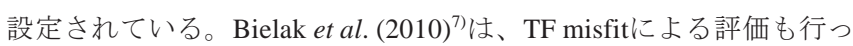
ており、時間-周波数領域のどこで誤差が生じているかを検討してい る。Nakamura et al. (2012) ${ }^{17)}$ も、3次元地下構造モデルによる地震動 シミュレーションにおいて、地下構造モデルの感度解析で時間-周波 数領域に変動が生じる部分をTF misfitにより評価している。このよ うに、TF misfitは時間-周波数領域の詳細な誤差を評価することがで きるため、シミュレーション同士のGOF評価に適していると考えら れる。2つ目として、D ragovich and L epage (2009) $\left.{ }^{18}\right)$ は、観測波形と計 算波形の複素平面上の距離により評価する指標FDE (the frequency domain error)を提案している。K risteková et al. ${ }^{15), 16)}$ のTF misfitは振幅 と位相それぞれで指標が作られており、両者は結びつけられていな いのに対し、FDEは複素平面上の距離を用いることでフーリエ振幅 とフーリエ位相の両者を考慮して評価することができる。加えて同 文献では、複素平面上の距離である誤差を位相の誤差と振幅の誤差
*1 (株小堀鐸二研究所 修士 (工学)

*2 (株)小堀鐸二研究所 統括部長・博士 (工学)

*3 (株小堀鐸二研究所 次長・博士 (工学)
Kobori Research Complex Inc., M.Eng.

Senior General Manager, Kobori Research Complex Inc., Dr.Eng.

Assist. General Manager, Kobori Research Complex Inc., Dr.Eng. 
Tablel GOF index of previous studies

\begin{tabular}{|c|c|c|c|c|}
\hline & Target & R anking & Application example & $\begin{array}{l}\text { Phase } \\
\text { GOF }\end{array}$ \\
\hline Anders on $(2004)^{6)}$ & $\begin{array}{l}\text { arias duration, energy duration, } \\
\text { arias intensity, energy integral, } \\
\text { PGA, PGV, PGD, response spectra, } \\
\text { F ourier spectra and cross-correlation }\end{array}$ & $\begin{array}{l}0-4: \text { poor fit } 4-6: \text { fair fit } \\
6-8: \text { good fit } 8-10: \text { excellent fit }\end{array}$ & $\begin{array}{l}\text { Bielak et al. }(2010)^{7)} \\
\text { Chaljub et al. }(2010)^{8)}\end{array}$ & $x$ \\
\hline Olsen and May hew (2010) ${ }^{9)}$ & $\begin{array}{l}\text { PGA, PGV, PGD, response spectra, } \\
\text { F ourier spectra, energy duration, } \\
\text { cumulative energy and cross-correlation }\end{array}$ & $\begin{array}{l}0-35: \text { too bad } 35-45: \text { poor fit } \\
45-65: \text { fair fit } 65-80: \text { very good fit } \\
80-100: \text { excellent fit }\end{array}$ & $\begin{array}{l}\text { R amirez-Guzman et al. }(2012)^{10)} \\
\text { D hakal and Y amanaka }(2012)^{11)}\end{array}$ & $x$ \\
\hline Dreger et al. $(2015)^{12)}$ & response spectra ( R otD50 PSAs ) & $\begin{array}{l}0-0.35: \text { Within Threshold } \\
0.35-0.7: \text { Potential Issues } \\
0.7-\infty: \text { Ploblematic }\end{array}$ & $\begin{array}{l}\text { Goulet et al. }(2015)^{13)} \\
\text { Melgar et al. }(2016)^{14)}\end{array}$ & $x$ \\
\hline Kristeková et al. $(2006,2009)^{15), 16)}$ & $\begin{array}{l}\text { Time-frequency amplitude and phase } \\
\text { by Wav elet transform }\end{array}$ & $\begin{array}{l}0-4: \text { poor fit } 4-6: \text { fair fit } \\
6-8: \text { good fit } 8-10: \text { excellent } \mathrm{fit}\end{array}$ & $\begin{array}{l}\text { Bielak et al. }(2010)^{7)} \\
\text { C haljub et al. }(2010)^{8)} \\
\text { Nakamura et al. }(2012)^{17)}\end{array}$ & O \\
\hline Dragovich and Lepage $(2009)^{18)}$ & $\begin{array}{l}\text { Distance on the complex plane of } \\
\text { measurement and calculation }\end{array}$ & - & $\begin{array}{l}\text { Lepage et al. }(2010)^{19)} \\
\text { Rodrigues et al. }(2012)^{20)}\end{array}$ & O \\
\hline
\end{tabular}

に分離し、それぞれを評価する指標も示している。ただし、位相と 振幅の誤差については1つの周波数のみの評価指標であり、幅を持つ た周波数帯域の指標も必要である。また、FDEはランクが設定され ていない。Lepage et al. (2010) ${ }^{199}$ は、鉄筋コンクリート造の建築物を 対象に、測定データの波形との適合度が最も高くなる解析モデルの パラメータをFDEにより評価している。FDEは建築物への適用例が 多く、地震動への適用例は少ない。

本研究では、上述の指標のうち波形の振幅と位相の両者を考慮で きるDragovich and Lepage ${ }^{18)}$ のFDEに着目し、指標の改良と高度化を 行う。はじめに、既往の指標では後述するように適切に評価できな い場合があったため、その改良指標を提案する。また、既往の振幅 と位相の評価指標は1つの周波数のみに対する指標であるため、幅を 持った周波数帯域に対する指標を提案する。これらの指標に対し、 Anderson6)等と同様に值に応じた4段階のランク [Excellent, Good, Fair, Poor]を設定寸る。これらの提案した指標が適切に適合度を評価寸る ことができるかを、位相と振幅に誤差を与えた簡易な模擬波形を用 いて検証する。さらに、位相差分と波形の包絡形の関係を利用して、 FDEを応用した波形の包絡形の評価方法を提案する。最後に、強震 動予測手法に関するベンチマークテストの計算波形同士の Verificationおよび地震動シミュレーションの観測記録との Validationに提案指標を用いた例を示し、適合度の定量的な評価指標 としての有用性を確認する。

\section{2. 適合度評価指標の定式化と判定基準}

\section{1 定式化}

Dragovich and Lepage $(2009)^{18)}$ のFEの概念図をFig.1に示す。FDE は、2つの波形、例えば観測波形 $X_{m}$ と計算波形 $X_{c}$ のフーリエ変換に 対して、その複素平面上の距離を誤差として評価する指標である。 $F D E$ は、 $k$ 次の周波数 $f_{k}$ における、 $X_{m} 、 X_{c}$ のフーリエ振幅 $A_{m_{k}} 、 A_{c_{k}}$ と誤差ベクトルの振幅 $A_{e_{k}}$ を用いて次式で定義される。

$$
\begin{aligned}
& F D E=\frac{\sum_{k=k_{1}}^{k_{2}} A_{e_{k}}}{\sum_{k=k_{1}}^{k_{2}}\left(A_{m_{k}}+A_{C_{k}}\right)}=\frac{\sum_{k=k_{1}}^{k_{2}} \sqrt{\left(R_{m_{k}}-R_{c_{k}}\right)^{2}+\left(I_{m_{k}}-I_{C_{k}}\right)^{2}}}{\sum_{k=k_{1}}^{k_{2}}\left(\sqrt{R_{m_{k}}{ }^{2}+I_{m_{k}}{ }^{2}}+\sqrt{{R_{C_{k}}{ }^{2}+I_{c_{k}}}^{2}}\right)} \\
& =\frac{\sum_{k=k_{1}}^{k_{2}} \sqrt{\left(A_{m_{k}}-A_{c_{k}} \cdot \cos \theta_{k}\right)^{2}+\left(A_{c_{k}} \cdot \sin \theta_{k}\right)^{2}}}{\sum_{k=k_{1}}^{k_{2}}\left(A_{m_{k}}+A_{c_{k}}\right)} .
\end{aligned}
$$

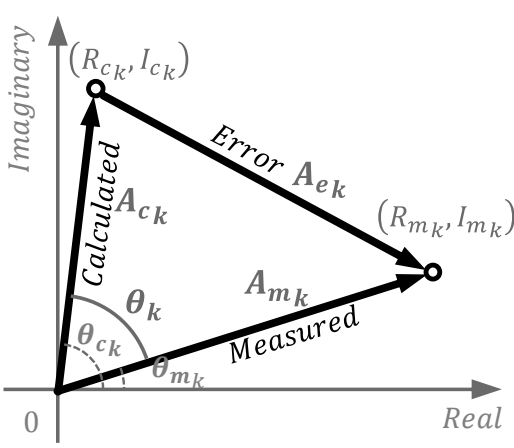

Fig. 1 Concept of FDE ${ }^{18)}$

$A_{e_{k}}$ は $X_{m} 、 X_{c}$ の $f_{k}$ における複素フーリエ係数 $\left(R_{m_{k}}, I_{m_{k}}\right) 、\left(R_{c_{k}}, I_{c_{k}}\right)$ の 複素平面上の距離であり、 $\theta_{k}$ は次式に表されるフーリエ位相 $\theta_{m_{k}}$ と $\theta_{c_{k}}$ の差である。

$$
\theta_{k}=\theta_{c_{k}}-\theta_{m_{k}}
$$

$F D E$ は誤差がない場合に0、誤差が最大の場合に1となる。分子が $A_{e_{k}}$ の $f_{k_{1}} \sim f_{k_{2}}$ の総和、分母が $A_{m_{k}}+A_{c_{k}}$ の $f_{k_{1}} \sim f_{k_{2}}$ の総和となっているた め、 $f_{k_{1}} \sim f_{k_{2}}$ の中で振幅の大きな周波数の誤差に大きな重みがかかる 指標となっている。

$1 つ の f_{k}$ における誤差 $\varepsilon_{T_{k}}$ はFDEから $\Sigma$ を除いた次式で定義される。

$$
\varepsilon_{T_{k}}=\frac{A_{e_{k}}}{A_{m_{k}}+A_{c_{k}}}=\frac{\sqrt{\left(A_{m_{k}}-A_{c_{k}} \cdot \cos \theta_{k}\right)^{2}+\left(A_{c_{k}} \cdot \sin \theta_{k}\right)^{2}}}{A_{m_{k}}+A_{c_{k}}} .
$$

位相誤差 $\varepsilon_{\theta_{k}}$ は式(3)に $A_{c_{k}}-A_{m_{k}}=0 \Leftrightarrow A_{c_{k}}=A_{m_{k}}$ を代入した

$$
\varepsilon_{\theta_{k}}=\frac{\sqrt{A_{m_{k}}{ }^{2}\left(1-\cos \theta_{k}\right)^{2}+A_{m_{k}}{ }^{2}\left(\sin \theta_{k}\right)^{2}}}{2 A_{m_{k}}}=\sqrt{\frac{1-\cos \theta_{k}}{2}}=\left|\sin \frac{\theta_{k}}{2}\right|
$$

で定義され、式(4)は $\theta_{k}=0^{\circ}$ で $\varepsilon_{\theta_{k}}=0 、\left|\theta_{k}\right|=180^{\circ}$ で $\varepsilon_{\theta_{k}}=1$ となる。

Dragovich and Lepage ${ }^{18)}$ は式(1)〜式(4)の他に、振幅誤差（ここでは $\varepsilon_{A 0_{k}}$ とする) を次式のように $\varepsilon_{\theta_{k}}$ との和が $\varepsilon_{T_{k}}$ となるよう定義している。

$$
\varepsilon_{T_{k}}=\varepsilon_{\theta_{k}}+\varepsilon_{A 0_{k}} \text {. }
$$

従って $\varepsilon_{A 0_{k}}$ は次式となる。

$$
\varepsilon_{A 0_{k}}=\varepsilon_{T_{k}}-\varepsilon_{\theta_{k}} .
$$

式(6)の $\varepsilon_{A 0_{k}}$ では、振幅誤差の評価は $A_{m_{k}}$ と $A_{c_{k}}$ の值よりも $\varepsilon_{\theta_{k}}$ の值に大 きく左右され、振幅誤差が適切に評価できないという問題点がある。 極端な例を挙げると、Fig.2のように $\theta_{k}=180^{\circ}$ の場合、 $A_{m_{k}} \neq A_{c_{k}}$ だ としても、 $\varepsilon_{A 0_{k}}=0$ で振幅の誤差はないという評価になり、矛盾が生 じる。そこで、このような矛盾が生じない振幅誤差の改良指標 $\varepsilon_{A_{k}}$ を 
新たに定義する。 $\varepsilon_{A_{k}}$ は、 $\theta_{k}=0$ を式(3)に代入した次式とする。

$$
\varepsilon_{A_{k}}=\frac{\sqrt{\left(A_{m_{k}}-A_{c_{k}} \cdot 1\right)^{2}+\left(A_{c_{k}} \cdot 0\right)^{2}}}{A_{m_{k}}+A_{c_{k}}}=\frac{\left|A_{m_{k}}-A_{c_{k}}\right|}{A_{m_{k}}+A_{c_{k}}} .
$$

式(7)の $\varepsilon_{A_{k}}$ は位相の影響を受けず、 $A_{c_{k}} / A_{m_{k}}=1$ で $\varepsilon_{A_{k}}=0 、 A_{c_{k}} / A_{m_{k}}=$ $0, \pm \infty て ゙ \varepsilon_{A_{k}}=1$ となり、振幅の誤差を適切に評価できる。式(4)と式 (7)を用いて式(3)を整理すると、 $\varepsilon_{T_{k}} 、 \varepsilon_{\theta_{k}} 、 \varepsilon_{A_{k}}$ の関係は次式となる。

$$
\varepsilon_{T_{k}}=\sqrt{\varepsilon_{A_{k}}{ }^{2}-\varepsilon_{A_{k}}{ }^{2} \varepsilon_{\theta_{k}}{ }^{2}+\varepsilon_{\theta_{k}}{ }^{2}} \text {. }
$$

単純な正弦波により振幅誤差 $\varepsilon_{A_{k}}$ を検証する。Table2に示すように、 Measuredの正弦波に対して、振幅や位相を変えた(1)〜 (4)のCal culated の正弦波の誤差 $\varepsilon_{T} 、 \varepsilon_{\theta} 、 \varepsilon_{A} 、 \varepsilon_{A 0}$ を評価する。(1)、(2)のように振幅と 位相のどちらかに誤差がある場合は、誤差のある方は $\varepsilon_{T}$ と同じ值、 ない方は0となる。この場合は $\varepsilon_{A}=\varepsilon_{A 0}$ であり、両者とも適切な評価 ができる。一方、(3)のよう位相は(2)、振幅は(1)と同じ誤差の場合、 $\varepsilon_{\theta}$ は(2)と同じ值だが、 $\varepsilon_{A 0}$ は(1)と異なる值となる。また、(4)のように 位相差が $180^{\circ}$ の場合は、前述のように、振幅に誤差があっても $\varepsilon_{A 0}=$ 0 で、誤差はないという評価になる。それに対し $\varepsilon_{A}$ は(3)、(4)ともに(1) と等しくなり、適切に䛊差を評価できている。

Dragovich and Lepage ${ }^{18)}$ は位相と振幅について1つの $f_{k}$ での誤差の 指標は示しているが、式(1)のFDEのような $f_{k_{1}} \sim f_{k_{2}}$ の周波数帯域にお ける誤差の指標は示していない。そこで、ここでは $f_{k_{1}} \sim f_{k_{2}}$ について の位相と振幅の誤差評価指標 $F D E_{\theta}$ と $F D E_{A}$ を定義する。式(1)を整理 すると次式となる。

$$
F D E=\frac{\sum_{k=k_{1}}^{k_{2}} \sqrt{\left(A_{m_{k}}-A_{c_{k}}\right)^{2}-\left(A_{m_{k}}-A_{c_{k}}\right)^{2}\left(\sin \frac{\theta_{k}}{2}\right)^{2}+\left(A_{m_{k}}+A_{c_{k}}\right)^{2}\left(\sin \frac{\theta_{k}}{2}\right)^{2}}}{\sum_{k=k_{1}}^{k_{2}}\left(A_{m_{k}}+A_{c_{k}}\right)} .
$$

位相誤差 $F D E_{\theta}$ は、式(4)の $\varepsilon_{\theta_{k}}$ の定義と同様に、式(9)に $A_{c_{k}}-A_{m_{k}}=0$ を代入した次式とする。

$$
F D E_{\theta}=\frac{\sum_{k=k_{1}}^{k_{2}}\left(A_{m_{k}}+A_{c_{k}}\right)\left|\sin \frac{\theta_{k}}{2}\right|}{\sum_{k=k_{1}}^{k_{2}}\left(A_{m_{k}}+A_{c_{k}}\right)} .
$$

振幅誤差 $F D E_{A}$ は、式(7)の $\varepsilon_{A_{k}}$ の定義と同様に、式(9)に $\theta_{k}=0$ を代入し た次式とする。

$$
F D E_{A}=\frac{\sum_{k=k_{1}}^{k_{2}}\left|A_{m_{k}}-A_{c_{k}}\right|}{\sum_{k=k_{1}}^{k_{2}}\left(A_{m_{k}}+A_{c_{k}}\right)}
$$

$F D E_{\theta}$ は $f_{k_{1}} \sim f_{k_{2}}$ の全周波数において $\theta_{k}=0^{\circ}$ の場合に0、 $\left|\theta_{k}\right|=180^{\circ}$ の 場合に1となる。 $F D E_{A}$ は $f_{k_{1}} \sim f_{k_{2}}$ の全周波数において $A_{c_{k}} / A_{m_{k}}=1$ の 場合に0、 $A_{c_{k}} / A_{m_{k}}=0$ または土地場合に1となる。FDE いずれも $f_{k_{1}} \sim f_{k_{2}}$ の中で振幅の大きな周波数の誤差に大きな重みが かかる指標となっている。

\section{2 適合度の判定基準}

前節で定義した誤差の評価指標の值と適合度およびランクの関係 を設定する。設定においては、振幅の適合度が既往研究の指標と概 ね対応するよう関数形を決める。

位相と振幅の適合度を各々 $G O F_{\theta_{k}}$ と $G O F_{A_{k}}$ とし、 $\varepsilon_{\theta_{k}}$ と $\varepsilon_{A_{k}}$ との関係 はAnderson') ${ }^{6}$ はristeková et al. ${ }^{16)}$ を参照して次式とする。

$$
\begin{gathered}
G O F_{\theta_{k}}=10 \exp \left(-a \varepsilon_{\theta_{k}}{ }^{b}\right) \\
G O F_{A_{k}}=10 \exp \left(-a \varepsilon_{A_{k}}{ }^{b}\right) \\
a>0, \quad b>0 .
\end{gathered}
$$

$a$ と $b$ は正の実数とし、振幅の適合度 $G O F_{A_{k}}$ と振幅比 $A_{c_{k}} / A_{m_{k}}$ との関

\begin{tabular}{|c|c|c|c|c|c|c|c|}
\hline & $A_{c} / A_{m}$ & $\begin{array}{l}\theta_{\mathrm{m}}-\theta_{\mathrm{c}} \\
\text { (deg.) }\end{array}$ & Waveform & $\varepsilon_{T}$ & $\varepsilon_{\theta}$ & $\varepsilon_{\mathrm{A}}$ & $\varepsilon_{\mathrm{A} 0}$ \\
\hline (1) & 0.50 & 0 & & 0.33 & 0.00 & 0.33 & 0.33 \\
\hline (2) & 1.00 & 45 & & 0.38 & 0.38 & 0.00 & 0.00 \\
\hline (3) & 0.50 & 45 & & 0.49 & 0.38 & 0.33 & 0.11 \\
\hline (4) & 0.50 & 180 & & 1.00 & 1.00 & 0.33 & 0.00 \\
\hline & & & & & & & \\
\hline
\end{tabular}
係が既往研究におけるこれらの関係と概ね同じとなるように、ここ では $a=8 、 b=2$ とする。 $\varepsilon_{\theta_{k}}$ と $\varepsilon_{A_{k}}$ は0 1の值をとるため、GOF $F_{\theta_{k}}$ 、 $G O F_{A_{k}}$ は0.003 100值をとり、值が高いほど適合度が高いことを示

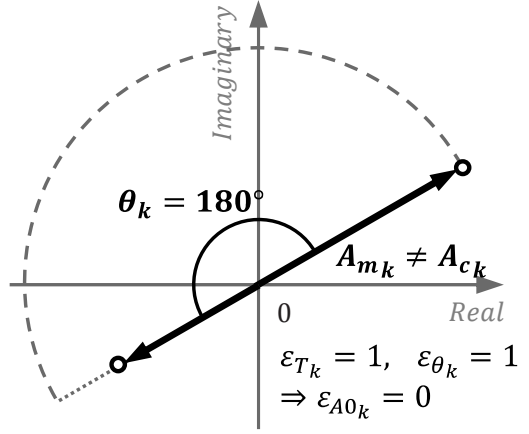

Fig.2 Schematic figure of Dragovich and Lepage ${ }^{18)}$ 's amplitude index

Table 2 Evaluated value of $\varepsilon_{T} \quad \varepsilon_{\theta} \quad \varepsilon_{A}$, and $\varepsilon_{A 0}$, for sine waves with different amplitude and phase

す。 $A_{c_{k}} / A_{m_{k}}$ とGOF$F_{A_{k}}$ および $\theta_{c_{k}}-\theta_{m_{k}}$ とGOF$F_{\theta_{k}}$ の関係について、Tablel に列挙した既往指標との比較をFig.3に示す。なお、Dreger et al. ${ }^{12)}$ の CGOFは小さいほど適合度が高い指標であるため、10(1-CGOF)とし た值を示している。Olsen and Mayhew ${ }^{91}$ はGOFの值が0〜100であるた め1/10の值を示している。Anderson') とKristeková et al. ${ }^{16)}$ のランクを 図中に、Olsen and Mayhew ${ }^{9)}$ とDreger etal. ${ }^{12)}$ のランクをそれぞれ図の 横に併記する。Fig.3(a)の振幅に関する比較から、本研究の $A_{c_{k}} / A_{m_{k}}$ と適合度の関係が既往指標と概ね対応していることが確認できる。 Fig.3(b)の位相に関しては、本研究はKristeková et al. ${ }^{16)}$ と比べて小さ い位相差で適合度の感度が高い。位相と振幅の両者を考慮した総合 的な波形の適合度 $G O F_{T_{k}}$ は次のように決める。まず、 $\varepsilon_{T_{k}}$ とGOF$F_{\theta_{k}}$ 、 $G O F_{A_{k}}$ の関係は、式(12)を $\varepsilon_{\theta_{k}} 、 \varepsilon_{A_{k}}$ について整理し、式(8)に代入した 次式となる。

$\varepsilon_{T_{k}}=\sqrt{\left\{-\frac{\ln \left(G O F_{A_{k}} / 10\right)}{a}\right\}^{\frac{2}{b}}-\left\{-\frac{\ln \left(G O F_{A_{k}} / 10\right)}{a}\right\}^{\frac{2}{b}}\left\{-\frac{\ln \left(G O F_{\theta_{k}} / 10\right)}{a}\right\}^{\frac{2}{b}}+\left\{-\frac{\ln \left(G O F_{\theta_{k}} / 10\right)}{a}\right\}^{\frac{2}{b}} .}$

ここで、位相と振幅の適合度が等しく $\alpha$ の值となるとき、GOF $F_{T_{k}}$ む $\alpha$ の 值となる（例えば $G O F_{A_{k}}=G O F_{\theta_{k}}=0.5$ のき $G O F_{T_{k}}=0.5$ となる）よ うに設定する。そこで、式(13)を

$$
G O F_{T_{k}}=G O F_{\theta_{k}}, \quad G O F_{T_{k}}=G O F_{A_{k}}
$$

で置き換えると次式となる。

$$
\varepsilon_{T_{k}}=\sqrt{\left\{-\frac{\ln \left(G O F_{T_{k}} / 10\right)}{a}\right\}^{\frac{2}{b}}-\left\{-\frac{\ln \left(G O F_{T_{k}} / 10\right)}{a}\right\}^{\frac{4}{b}}+\left\{-\frac{\ln \left(G O F_{T_{k}} / 10\right)}{a}\right\}^{\frac{2}{b}}} .
$$

これを $G O F_{T_{k}}$ について整理した次式を波形の適合度 $G O F_{T_{k}}$ とする。 


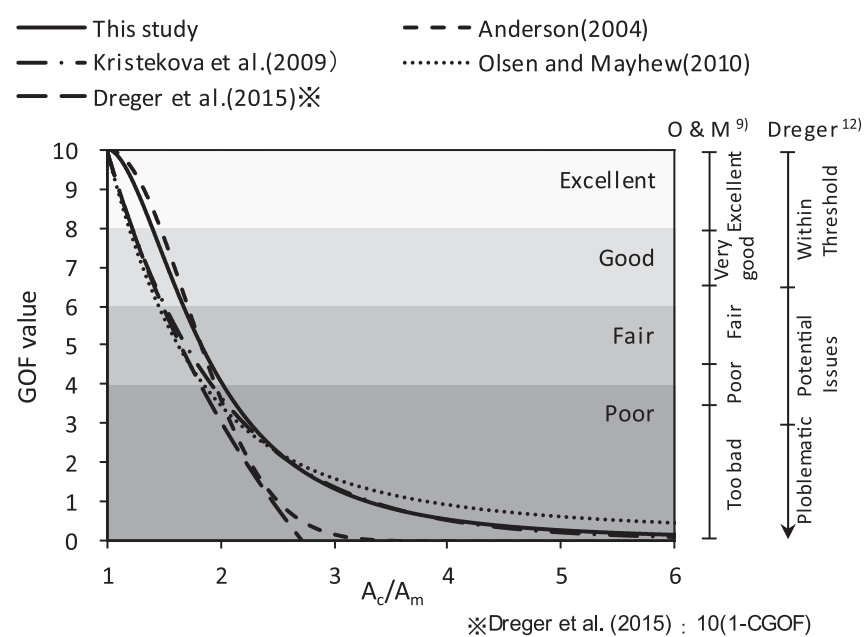

(a) Amplitude

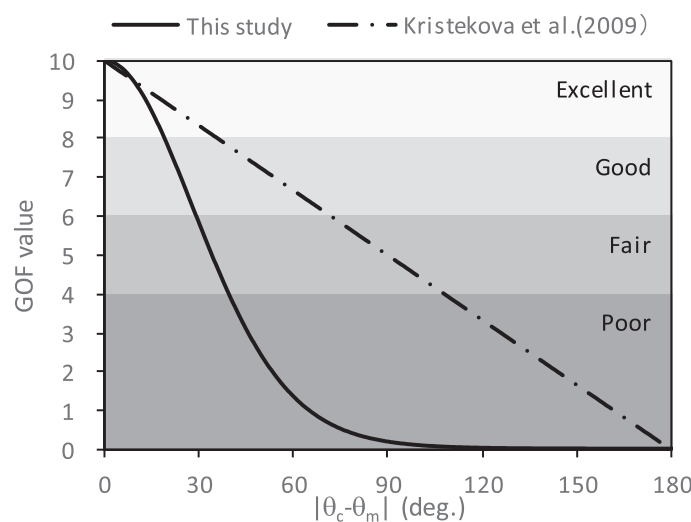

(b) Phase

Fig.3 Comparison of GOF indexes

$$
G O F_{T_{k}}=10 \exp \left\{-a\left(1-\sqrt{1-\varepsilon_{T_{k}}^{2}}\right)^{b / 2}\right\} .
$$

Table3に式(12)で定義した $G O F_{\theta_{k}} 、 G O F_{A_{k}}$ と式(16)で定義したGOF $F_{T_{k}}$ の 関係を示す。Table4に適合度の高い順に設定した4段階のランク [ Excellent, Good, Fair, Poor ] とGOFの関係を示す。ランクの決め方は A nderson ${ }^{6)} 、 K$ risteková etal. ${ }^{16)}$ と同じとし、4末満をPoor、4以上6未満 をFair、6以上8未満をGood、8以上をExcellentとする。

幅を持った周波数帯域の指標である $F D E 、 F D E_{\theta} 、 F D E_{A}$ の判定基準 $G O F_{T} 、 G O F_{\theta} 、 G O F_{A}$ は、式(12) と式(16)のGOF $F_{T_{k}} 、 G O F_{\theta_{k}} 、 G O F_{A_{k}} の \varepsilon_{T_{k}}$ 、 $\varepsilon_{\theta_{k}} 、 \varepsilon_{A_{k}}$ を $F D E 、 F D E_{\theta} 、 F D E_{A}$ に置き換えて求める。

\section{3 模擬波形による指標の検証}

2.1、2.2節で定義したGOF $、 G O F_{\theta} 、 G O F_{A}$ が、誤差を与えた波形を 適切に評価できるか検証する。検証には複数の周波数 $(f=0.1,0.2,0.5$, $1.0 \mathrm{~Hz}$ )の正弦波を合成した波形を用いる。正解とする波形をX m1、 それに対し異なる誤差を与えた波形をそれぞれXcla、X c lb とする。 それらの各周波数の振幅と位相角をTable5に、波形をFig.4に示す。

$\mathrm{Xml}$ に対するXcla、Xclbの適合度の評価として、Fig.5にf $=0.1,0.2$ ， $0.5,1.0 \mathrm{~Hz}$ におけるGOF $F_{T_{k}} 、 G O F_{\theta_{k}} 、 G O F_{A_{k}}$ を、Fig.6にf $=0.1 \sim 1.0 \mathrm{~Hz}$ の $G O F_{T} 、 G O F_{\theta} 、 G O F_{A}$ を示す。Xclaのf $=0.2,1.0 \mathrm{~Hz} 、 \mathrm{Xclb} の \mathrm{f}=0.1,0.5 \mathrm{~Hz}$ においては、両者ともX $\mathrm{ml}$ に対する振幅比が $A_{c_{i}} / A_{m_{i}}=3$ 、位相差が $\theta_{c_{i}}-\theta_{m_{i}}=60^{\circ}$ と等しいため、XclaとXclbのFig.5のGOF $T_{T_{k}} 、 G O F_{\theta_{k}}$ 、 $G O F_{A_{k}}$ は等しくなる。一方、Fig.6のGOF $、 G O F_{\theta} 、 G O F_{A}$ は振幅の大き な周波数の誤差に大きな重みがかかる指標である。Xmlの $f=0.2$,
Table3 Matrix of $G O F_{\theta_{k}}, G O F_{A_{k}}$ and $G O F_{T_{k}}$

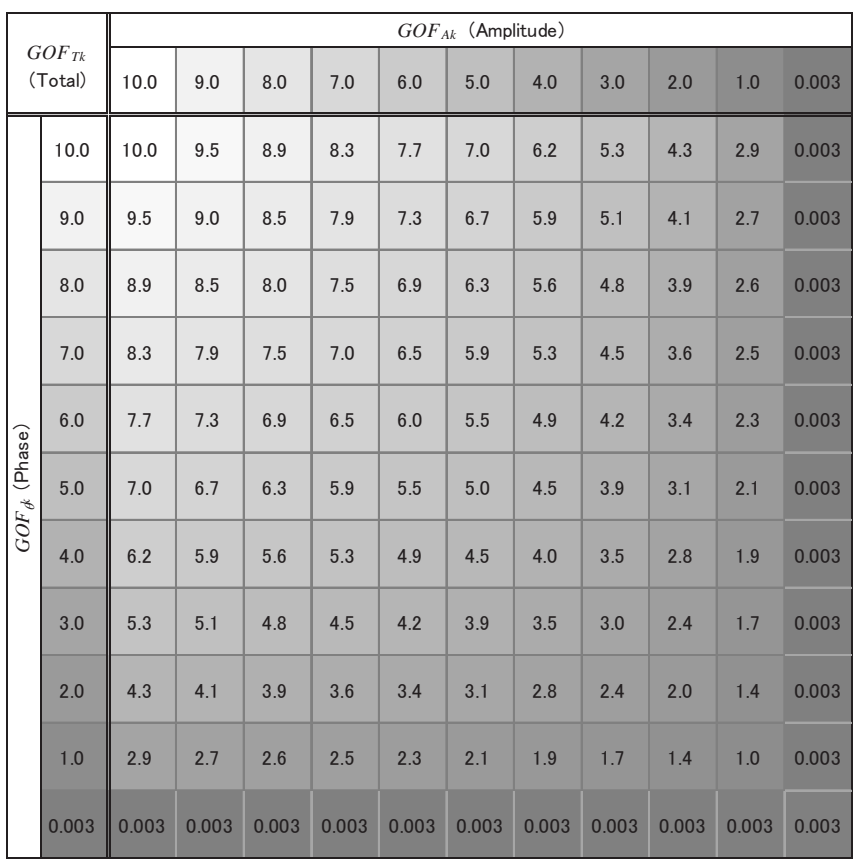

Table4 Rank of $G O F_{\theta_{k}}, G O F_{A_{k}}$ and $G O F_{T_{k}}$

\begin{tabular}{|c|c|}
\hline Rank & $\mathrm{GOF}_{\mathrm{Tk}}, \mathrm{GOF}_{\theta \mathrm{K}^{\prime}} \mathrm{GOF}_{\mathrm{Ak}}$ \\
\hline \multirow{2}{*}{ Excellent } & 10 \\
\cline { 2 - 2 } & 9 \\
\hline \multirow{2}{*}{ Good } & 8 \\
\cline { 2 - 2 } & 7 \\
\hline \multirow{2}{*}{ Fair } & 6 \\
\cline { 2 - 2 } & 5 \\
\hline \multirow{3}{*}{ Poor } & 4 \\
\cline { 2 - 2 } & 3 \\
\cline { 2 - 2 } & 2 \\
\cline { 2 - 2 } & 1 \\
\hline
\end{tabular}

Table5 Amplitude and phase at each frequency of Xm1, Xcla and Xclb (synthesized sine waves)

\begin{tabular}{ccccccccc}
\hline & \multicolumn{4}{c}{ Amplitude } & \multicolumn{4}{c}{ Phase(deg.) } \\
\hline freq $(\mathrm{Hz})$ & 0.1 & 0.2 & 0.5 & 1 & 0.1 & 0.2 & 0.5 & 1 \\
\hline \hline $\mathrm{Xm} 1$ & 1 & 0.1 & 1 & 0.1 & 0 & 0 & 0 & 0 \\
$\mathrm{Xc1a}$ & 1 & 0.3 & 1 & 0.3 & 0 & 60 & 0 & 60 \\
$\mathrm{Xc1b}$ & 3 & 0.1 & 3 & 0.1 & 60 & 0 & 60 & 0 \\
\hline
\end{tabular}

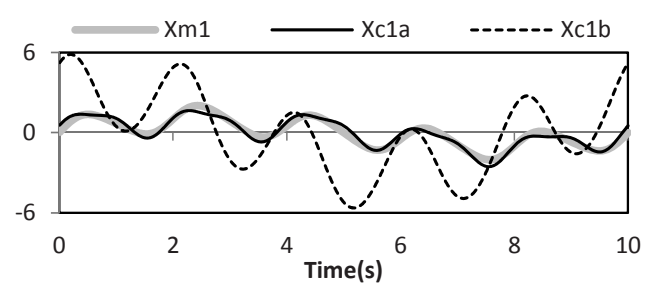

Fig.4 Waveform of Xm1, Xcla and Xc1b

$1.0 \mathrm{~Hz}$ の振幅はf $=0.1,0.5 \mathrm{~Hz}$ の1/10倍であるため、Xm1に対するGOF $G O F_{\theta} 、 G O F_{A}$ は、Xclaの方がXclbより大きくなる。Fig.4の波形から もXclaの方がXclbよりXm1に近いことが確認できる。よって、各周 波数のGOF $F_{T_{k}} 、 G O F_{\theta_{k}} 、 G O F_{A_{k}}$ が等しい值であっても、周波数間の相 対的な振幅の違いによって、波形の誤差GOFT、GOF $、 G O F_{A}$ は異な る。Table4に従いXclaとXc1bのランクを判定すると、XclaはGOF $G O F_{\theta} 、 G O F_{A}$ のいずれもExcellent、XclbはGOF $、 G O F_{\theta} 、 G O F_{A}$ のいず 


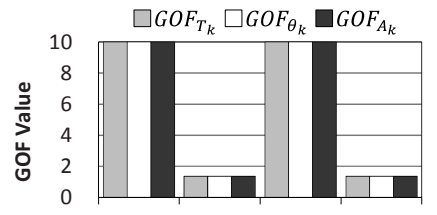

$\begin{array}{llll}0.1 \mathrm{~Hz} & 0.2 \mathrm{~Hz} & 0.5 \mathrm{~Hz} & 1 \mathrm{~Hz}\end{array}$ (a) GOF of Xcla to Xm1

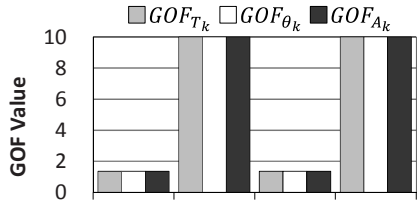

$\begin{array}{llll}0.1 \mathrm{~Hz} & 0.2 \mathrm{~Hz} & 0.5 \mathrm{~Hz} & 1 \mathrm{~Hz}\end{array}$ (b) GOF of Xc1b to Xm1 Fig.5 GOF $_{T_{k}}, G O F_{\theta_{k}}, G O F_{A_{k}}$ (each frequency: $\mathrm{f}=0.1,0.2,0.5,1.0 \mathrm{~Hz}$ )

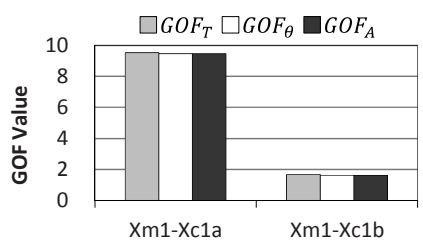

Fig.6 GOF $, G_{T} O F_{\theta}, G O F_{A}$ (frequency band: $\mathrm{f}=0.1$ to $1.0 \mathrm{~Hz}$ )

れもFairとなる。

なお、Anderson $)^{6}$ により適合度を評価すると、フーリエ振幅はXcla、 Xc1bともに5.1でFair、波形の最大振幅はXclaが9.4でExcellent、Xc1b が0.4でFairとなる。Anderson包の指標には周波数間の振幅の大小は影 響しないため、フーリエ振幅のみの評価では波形の見た目の適合度 とは一致せず、最大振幅の評価と併せて判断が必要となる。

\section{3. 位相差分を用いた波形の包絡形の適合度評価}

\section{1 定式化}

2章では波形のフーリエ振幅とフーリエ位相に基づき誤差を評価 する $F D E 、 F D E_{\theta} 、 F D E_{A}$ を示した。一方、地震動の観測波形と計算波 形の適合度評価では包絡形に着目することも多い。詳細な位相角は 一致していなくても、波形の包絡形が一致していれば観測記録の再 現性は高いと評価する場合もある。そこで本章では、FDEを応用し て波形の包絡形の誤差を評価する方法を提案する。

波形の包絡形の適合度評価には位相差分と包絡形の関係を用いる。 位相差分とは、隣り合う周波数におけるフーリエ位相の差分である。 位相差分と包絡形の関係については、大崎ほか(1978) ${ }^{21)}$ が位相差分 の頻度分布と地震波の包絡形が類似していることを示している。ま た、位相差分を周波数刻みで除した值である群遅延時間（和泉・勝 倉、198322)）について、Katukuraetal. (1978) ${ }^{23)}$ は、群遅延時間が成分 波の時間軸上の重心位置を表しており、群遅延時間をフーリエ振幅 で重み付けした平均值と分散が元の波形の包絡形の重心と時間軸上 の広がりを表すことを示している。位相差分が時間軸上の重心とな ることについては、山根・長橋(2002) ${ }^{24)}$ がうなりの概念を用いること により、理論的に示している。

ここでは山根・長橋24)の定式化を参照し、フーリエ位相で表され る波形のフーリエ級数の式を、位相差分で表される式に変換する。 時刻歴波形 $x(t)$ はフーリエ級数に展開すると次式で表される。

$$
x(t)=\sum_{k=-\infty}^{\infty} A_{k} \cos \left(\omega_{k} t+\theta_{k}\right) .
$$

ここに、 $A_{k}$ と $\theta_{k}$ は $k$ 次の角周波数 $\omega_{k}$ におけるフーリエ振幅とフーリ エ位相である。山根・長橋 ${ }^{24}$ は、式(17)の任意の隣り合う成分波を重 初合わせた合成波（以降、合成波という）を用いて、位相差分の持 つ物理的意味を考察している。その際、位相差分に着目しているこ とからフーリエ振幅は1.0と仮定している。本研究では、合成波の位
相だけではなく振幅も評価対象とするため、フーリエ振幅を1.0とせ ずに定式化する。隣り合う周波数の差 $\Delta \omega$ と、位相差分 $\Delta \theta_{k}$ を、

$$
\begin{array}{ll}
\Delta \omega_{k}=\omega_{k+1}-\omega_{k} & (k=\cdots-1,0,1,2, \cdots) \\
\Delta \theta_{k}=\theta_{k+1}-\theta_{k} & (k=\cdots-1,0,1,2, \cdots)
\end{array}
$$

（ただし、 $\Delta \theta_{k}$ は区間 $[0,-2 \pi]$ の值とする）とすると、式(17)は合成波 を用いて次式で表される。

$$
\begin{aligned}
& x(t)=\sum_{k=-\infty}^{\infty} \frac{1}{2}\left\{A_{k} \cos \left(\omega_{k} t+\theta_{k}\right)+A_{k+1} \cos \left(\omega_{k+1} t+\theta_{k+1}\right)\right\} \\
& =\sum_{k=-\infty}^{\infty}\left[\frac{A_{k}}{2} \cos \left\{\left(\frac{\omega_{k}+\omega_{k+1}}{2}-\frac{\Delta \omega_{k}}{2}\right) t+\frac{\theta_{k}+\theta_{k+1}}{2}-\frac{\Delta \theta_{k}}{2}\right\}\right. \\
& \left.+\frac{A_{k+1}}{2} \cos \left\{\left(\frac{\omega_{k}+\omega_{k+1}}{2}+\frac{\Delta \omega_{k}}{2}\right) t+\frac{\theta_{k}+\theta_{k+1}}{2}+\frac{\Delta \theta_{k}}{2}\right\}\right] \\
& =\sum_{k=-\infty}^{\infty}\left\{\frac{A_{k}+A_{k+1}}{2} \cos \left(\frac{\Delta \omega_{k}}{2} t+\frac{\Delta \theta_{k}}{2}\right) \cdot \cos \left(\frac{\omega_{k}+\omega_{k+1}}{2} t+\frac{\theta_{k}+\theta_{k+1}}{2}\right)\right. \\
& \left.\quad+\frac{A_{k}-A_{k+1}}{2} \sin \left(\frac{\Delta \omega_{k}}{2} t+\frac{\Delta \theta_{k}}{2}\right) \cdot \sin \left(\frac{\omega_{k}+\omega_{k+1}}{2} t+\frac{\theta_{k}+\theta_{k+1}}{2}\right)\right\} .
\end{aligned}
$$

式(20) \{\}内の第1項と第2項は、各項の第3因子で表される角周波数 $\left(\omega_{k}+\omega_{k+1}\right) / 2$ で単振動する波形に、振幅 $\left(A_{k}+A_{k+1}\right) / 2$ または $\left(A_{k}-A_{k+1}\right) / 2$ に対し、 $\Delta \omega_{k} / 2$ で振動する、位相角 $\Delta \theta_{k} / 2$ の包絡関数を 乗じたうなり波形となる。 $\Delta \omega_{k}$ と波形の全長 $T_{d}$ の関係は、

$$
\Delta \omega_{k}=2 \pi / T_{d}
$$

であるため、包絡関数の周期は $2 T_{d}$ となる。式(21)右辺は次数 $k$ に依 存しないため、第 1 項、第 2 項の包絡関数は $k$ に寄らず全て周期 $2 T_{d}$ と なる。以降、 $\Delta \omega_{k}=\Delta \omega$ とする。式(20) \{\} 内の第1項は、うなりの振 幅が最大となる時間軸上での腹の位置を至とすると、

$$
\bar{t} / T_{d}=-\Delta \theta_{k} / 2 \pi
$$

となる。全長 $T_{d}$ を $2 \pi$ に対応させると腹の位置 $\bar{l}$ は $-\Delta \theta_{k}$ に対応する 24$) 。$ 式(17)のフーリエ級数が式(20)の合成波で表される関係の概念図 をFig.7に示す。単振動する波の足し合わせで表されるフーリエ級数 (Fig.7左)は、隣り合う周波数の成分波を1/2ずつ合成した波の足し合 わせで表され、その合成波はうなり波形となる(Fig.7右)。式(20)にお いて、 \{\} 内の第1項が支配的な場合、寸なわち $A_{k}+A_{k+1}$ が $A_{k}-A_{k+1}$ に対して十分大きい場合、合成波の包絡形は第1項の包絡関数(Fig.7 の灰色線) とほぼ一致する。一般的に $A_{k}+A_{k+1}$ は $A_{k}-A_{k+1}$ に対して 十分大きいと考えられるため、本研究では式(20)を\{\}内の第1項の みで近似した次式で表す。

$$
x(t) \approx \sum_{k=-\infty}^{\infty} \frac{A_{k}+A_{k+1}}{2} \cos \left(\frac{\Delta \omega}{2} t+\frac{\Delta \theta_{k}}{2}\right) \cdot \cos \left(\frac{\omega_{k}+\omega_{k+1}}{2} t+\frac{\theta_{k}+\theta_{k+1}}{2}\right) .
$$

2章では、誤差評価において波形のフーリエ振幅 $A_{k}$ とフーリエ位相 $\theta_{k}$ を用いた。本章では、これに代わって次式で表す式(23)の包絡関数 の振幅 $\overline{A_{k}}$ と位相 $\overline{\Delta \theta_{k}}$ を用いる。

$$
\begin{array}{ll}
\overline{A_{k}}=\left(A_{k}+A_{k+1}\right) / 2 & (k=\cdots-1,0,1,2, \cdots) \\
\overline{\Delta \theta_{k}}=\Delta \theta_{k} / 2 & (k=\cdots-1,0,1,2, \cdots) .
\end{array}
$$

観測波形々計算波形の $k$ 次の包絡関数の振幅を $\overline{A_{m_{k}}}$ と $\overline{A_{c_{k}}}$ 、包絡関数 の位相を $\overline{\Delta \theta_{m_{k}}}$ と $\overline{\Delta \theta_{c_{k}}}$ とする。これらを式(1)、式(10)、式(11)のフーリ 工振幅 $A_{m_{k}}$ と $A_{c_{k}}$ 、フーリエ位相 $\theta_{m_{k}}$ と $\theta_{c_{k}}$ と置き換えた以下の式を、 包絡形の誤差を評価する指標 $E-F D E 、 E-F D E_{\theta} 、 E-F D E_{A}$ とする。

$$
E-F D E=\frac{\sum_{k=k_{1}}^{k_{2}} \sqrt{\left\{\overline{A_{m_{k}}}-\overline{A_{c_{k}}} \cdot \cos \left(\overline{\Delta \theta_{c_{k}}}-\overline{\Delta \theta_{m_{k}}}\right)\right\}^{2}+\left\{\overline{A_{c_{k}}} \cdot \sin \left(\overline{\Delta \theta_{c_{k}}}-\overline{\Delta \theta_{m_{k}}}\right)\right\}^{2}}}{\sum_{k=k_{1}}^{k_{2}}\left(\overline{A_{m_{k}}}+\overline{A_{c_{k}}}\right)}
$$




$$
\begin{gathered}
E-F D E_{\theta}=\frac{\sum_{k=k_{1}}^{k_{2}}\left(\overline{A_{m_{k}}}+\overline{A_{c_{k}}}\right)\left|\sin \frac{\overline{\theta_{c_{k}}}-\overline{\Delta \theta_{m_{k}}}}{2}\right|}{\sum_{k=k_{1}}^{k_{2}}\left(\overline{A_{m_{k}}}+\overline{A_{c_{k}}}\right)} \\
E-F D E_{A}=\frac{\sum_{k=k_{1}}^{k_{2}}\left|\overline{A_{m_{k}}}-\overline{A_{c_{k}}}\right|}{\sum_{k=k_{1}}^{k_{2}}\left(\overline{A_{m_{k}}}+\overline{A_{c_{k}}}\right)} .
\end{gathered}
$$

包絡関数は $\overline{\Delta \theta_{m_{k}}}$ と $\overline{\Delta \theta_{c_{k}}}$ が $180^{\circ}$ ずれている場合、寸なわち $T_{d}$ ずれて いる場合に最も誤差が大きいという評価となる。

$E-F D E 、 E-F D E_{\theta} 、 E-F D E_{A}$ の適合度 $E-G O F_{T} 、 E-G O F_{\theta} 、 E-G O F_{A}$ に

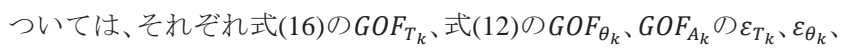
$\varepsilon_{A_{k}}$ を $E-F D E 、 E-F D E_{\theta} 、 E-F D E_{A}$ に置き換えて求める。

ここで、位相差分 $\Delta \theta_{k}$ を算出する際の留意点を示す。波形データの フーリエ変換においては、高速フーリエ変換を用いるために、波形 データに後続の０を付加する場合が多い。式(22)で示したように、 $-\Delta \theta_{k}$ と $2 \pi$ の比はうなりの最大振幅の時間 $\bar{t}$ と波形の全長 $T_{d}$ の比に等 しいため、後続の 0 を付加した場合は付加しない場合に対して $-\Delta \theta_{k}$ が小さく求められる。従って、適合度評価において、観測波形 と計算波形に同様に後続の0を付加した場合は、付加しない場合に 対して $\left|\Delta \theta_{c_{k}}-\Delta \theta_{m_{k}}\right|$ |小さくなり、適合度が高いという評価になっ てしまう。このようなデータ処理の過程によって適合度の評価結果 が変わることを回避するため、評価においては次式の補正を行った $\Delta \theta_{k}$ を用いることとする。

$$
\Delta \theta_{k}=\Delta \theta_{0_{k}} \times \frac{T_{d_{0}}}{T_{d}} \quad(k=\cdots-1,0,1,2, \cdots) .
$$

ここに、 $\Delta \theta_{0_{k}}$ と $T_{d_{0}}$ は後続の0 を付加した際の波形の位相差分と波形 の全長である。

\section{2 波形指標と包絡形指標の違い}

模擬波形を用いて、2章で示した波形を評価する指標と本章で示し た包絡形を評価する指標の違いを示す。模擬波形は、2.3節と同様に、 Table6に示寸振幅と位相を持つ複数の周波数の正弦波を合成した Xm2とXc2を用いる。波形をFig.8に示す。Xm2とXc2は振幅がほぼ同 じで、逆位相の波であるが、包絡形はほぼ一致している。

Xm2 とXc2の適合度をFig.9に示す。Fig.9(a)は2章で示した波形指 標による評価である。GOF $F_{A}$ は約10、GOF $F_{\theta}$ と $G O F_{T}$ は約0であるため、 振幅の適合度はExcellentと高いが、位相の適合度が低く、波形全体 の適合度も低いPoorの評価となる。一方、Fig.9(b)は本章で示した包 絡形指標による評価である。E-GOF $F_{A}$ は GOF と同様に約 10 となり、振 幅の適合度はExcellentである。包絡関数の位相を評価するE-GOF 約10でExcellentとなり、その結果 $E-G O F_{T}$ も約10でExcellentとなる。 このように本章で示した指標を用いることで、包絡形の観点から見 た波形の適合度を評価することができる。

\section{4. 適合度評価指標の適用}

\section{1 強震動予測手法に関するベンチマークテスト}

2 章、3 章で定義した指標について、適合度評価への適用例を示 す。本節では、強震動予測手法に関するベンチマークテストにおけ る V erificationに用いる例として、吉村ほか $\left.(2013)^{25}\right)$ の計算結果の適 合度を評価する。ベンチマークテストのような計算波形同士の適合 度は、波形の振幅や位相の僅かな違いを評価できるよう、フーリエ 振幅とフーリエ位相を評価するGOF $、 G O F_{\theta} 、 G O F_{A}$ を用いる。

吉村ほか ${ }^{25}$ は、関東平野の 3 次元地盤モデルを用いた数值解析手 法による地震動シミュレーションに関して、複数のベンチマークテ

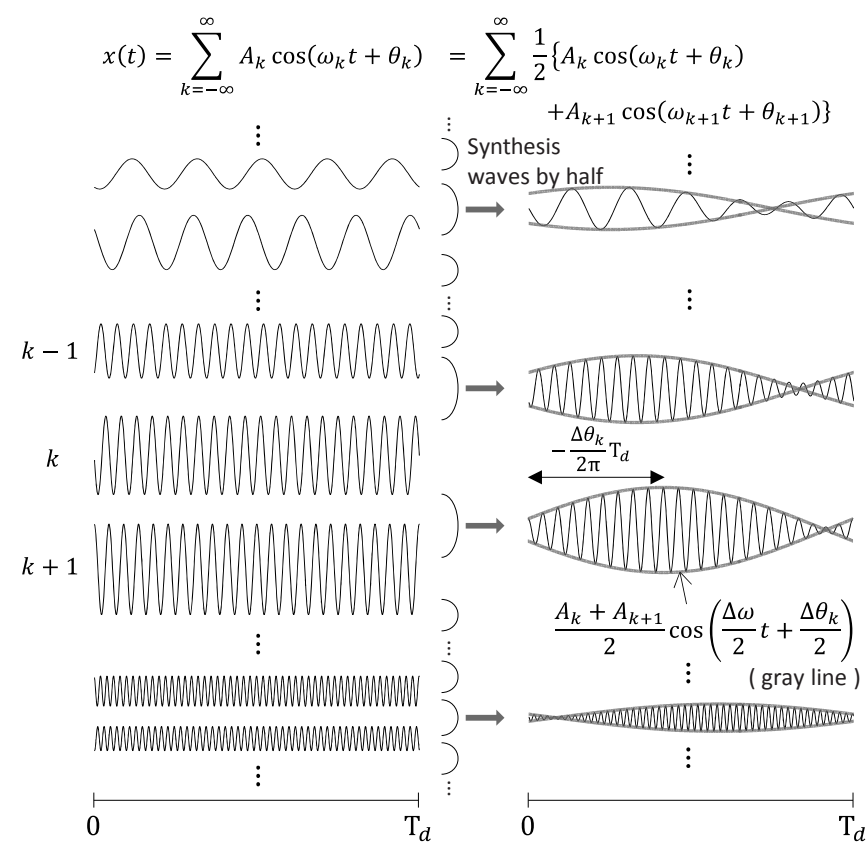

Fig.7 Concept of Equations (17) and (20). Fourier series (left) Synthesis of adjacent component waves (right)

Table6 Amplitude and phase of $\mathrm{Xm} 2$ and $\mathrm{Xc2}$

\begin{tabular}{cccccc}
\hline \multicolumn{2}{c}{ freq $(\mathrm{Hz})$} & 2 & 2.1 & 2.2 & 2.3 \\
\hline \hline \multirow{2}{*}{ Amp. } & $X_{m} 2$ & 0.7 & 1.2 & 1.3 & 0.9 \\
& $X c 2$ & 0.8 & 1.2 & 1.3 & 0.7 \\
\hline Phase & $X m 2$ & -60 & -150 & 120 & 30 \\
(deg.) & $X c 2$ & 120 & 30 & -60 & -150
\end{tabular}
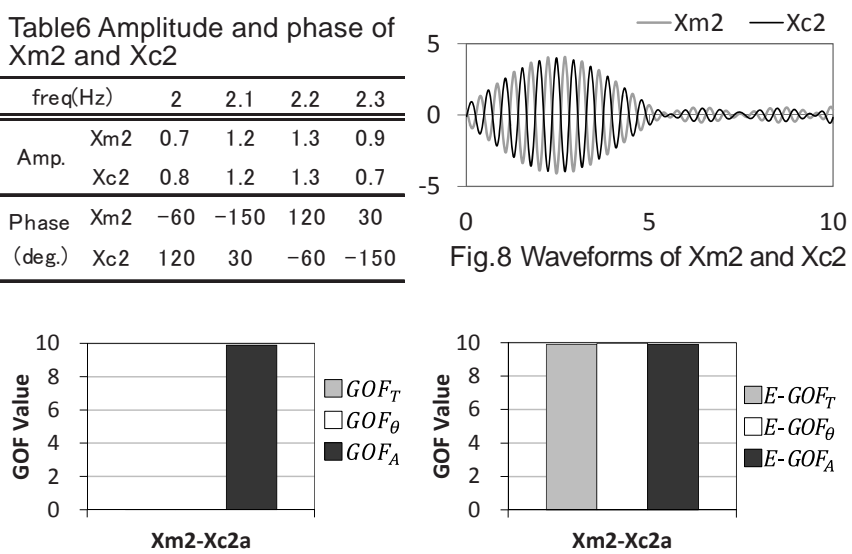

(a) $\mathrm{GOF}_{T}, \mathrm{GOF}_{\theta}, \mathrm{GOF}_{\mathrm{A}}$

(b) $E-G O F_{T}, E-G O F_{\theta}, E-G O F_{A}$ Fig. 9 GOF of $X c 2$ and $X c 2(f=2.0 \sim 2.3 \mathrm{~Hz})$

ストを実施している。このうち N51 モデルと N54 モデルを対象と する。N 51 は 1990 年神奈川県西部の地震(M j5.1)を点震源により評 価したケースである。N54 はN51 で参加者により異なっていた 3 次 元差分法の格子間隔や地盤物性值などの計算条件を可能な限り統一 して再計算したケースである。吉村ほか ${ }^{25)}$ は、N54 で参加者の計算 波形の適合度が向上することを波形の比較により示している。

ベンチマークテストには 7 つのームが参加しているが、ここで はそのうち N54 で再計算を行った Citak・松島・Graves と川辺の 2 チームの計算波形について、永野の計算波形との適合度を評価寸る。 計算波形のうち、SMK (寒川) の Y (EW)成分の速度波形を対象とす る。N51 と N54の Citak らと川辺の永野との比較について、速度波 形、フーリエ振幅とフーリエ位相の比較を Fig.10 に示す。永野の結 果はN 51 と N54 で同じである。計算結果は有効振動数である $0.33 \mathrm{~Hz}$ から直線で落ち始め $0.4 \mathrm{~Hz}$ で 0 となるスロープを持つローパスフィ ルターがかけられている。0 0.4Hzにおいての、永野に対する Citak らと川辺のN51 と N54 の適合度を Table7 に示す。N51 のGOF $G O F_{A} 、 G O F_{T}$ は Citak らが全て Fair、川辺が全て Poor であるのに対 


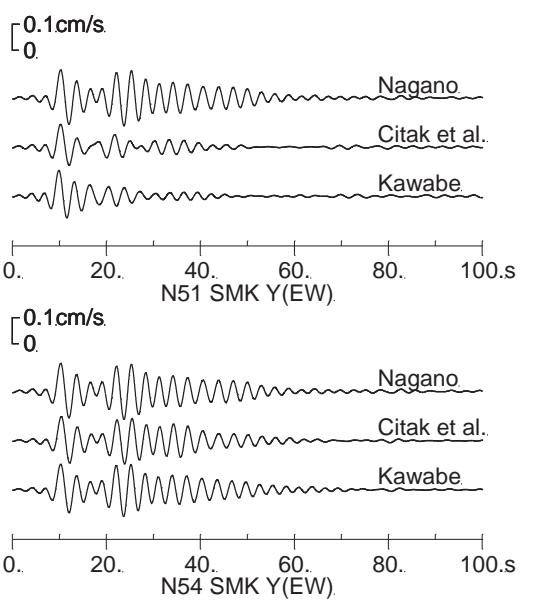

(a) Velocity waveforms
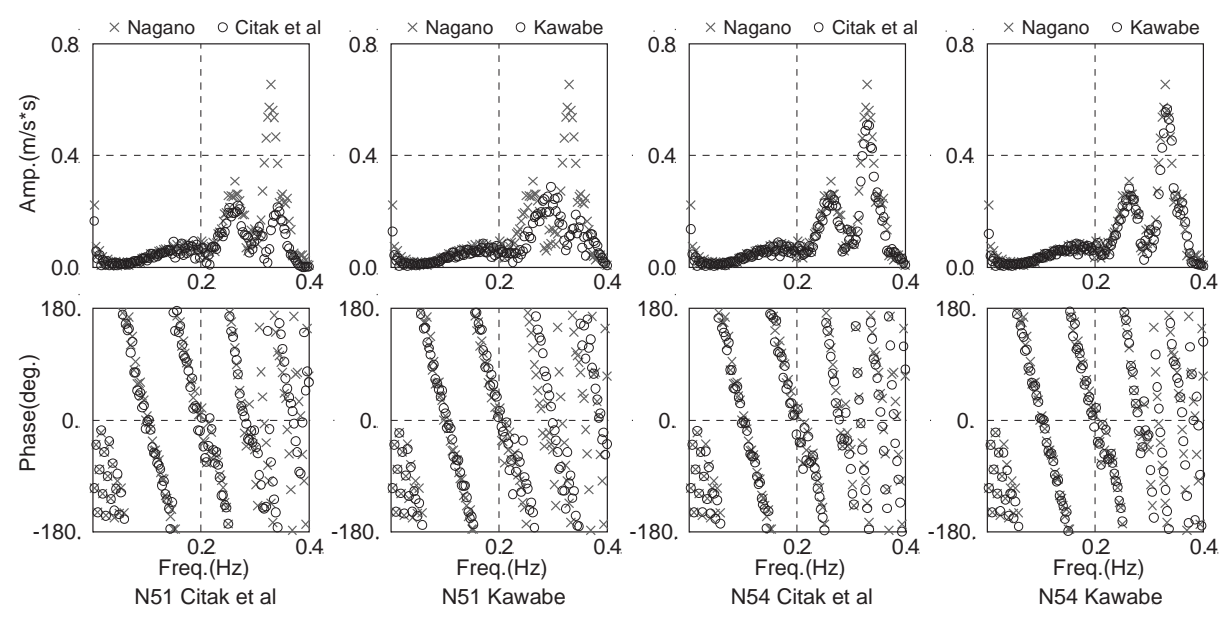

(b) Fourier amplitude (top) and Fourier phase (bottom).

Fig.10 Benchmark test by Yoshimura et al. $(2013)^{25)}$ (N51 and N54 model, SMK, Y (EW)).

し、N54は両者とも全てExcellent となっており、波形の適合度が振 幅、位相ともにN51から向上していることを示している。Fig.10(b) のフーリエ振幅とフーリエ位相からも、比較的振幅の大きな $0.3 \mathrm{~Hz}$ 前後において、永野との適合度が N51では悪いが、N54では良いこ とが確認できる。本指標は、前述したように振幅の大きな周波数で の誤差に大きな重みがかかるため、N51 と N54のような違いは反映 されやすい。

吉村ほか 25)では、適合度が波形の見た目から定性的に述べられて いる。このような定性的な評価に加えて、本研究で提案した指標を 用いて適合度を定量的に示寸ことで、ベンチマークテストに対して より客観的な判断をすることができる。

\section{2 地震動シミュレーションと観測記録}

本節では、地震動シミュレーションの物理モデルの妥当性を確認 する Validation に用いる例として、元木ほか(2015) $)^{5}$ にる 2004 年 留萌支庁南部の地震 $(\mathrm{Mj} 6.1)$ の地震動シミュレーションと観測記録 の適合度を評価する。3 章で述べたように、地震動シミュレーショ ンと観測記録の適合度は波形の包絡形に着目寸ることも多いため、 適合度評価には包絡関数の振幅と位相を評価する $E-G O F 、 E-G O F_{\theta}$ 、 $E-G O F_{A}$ を用いる。

元木ほか ${ }^{5}$ は波数積分法や三次元有限差分法により 2004 年留萌 支庁南部の地震の震源近傍の地震動をシミュレーションしている。 ここでは強震動生成域(SMGA)の大きさを調整し、地盤の不均質性 (相関距離 $\mathrm{a}=5 \mathrm{~km}$ ) を考慮した、HKD020 (K-net 港町)と RMIH04 (KiK-net 小平東、地中観測点)のシミュレーション結果と観測記録 の適合度を評価する。 HKD020 と RMIH04 の速度波形、フーリエ 振幅、フーリエ位相の観測記録とシミュレーションの比較を Fig.11 に示す。元木ほか 5)では HKD020 で 0.1〜3.0Hz、RMIH04 で 0.1 〜 $5.0 \mathrm{~Hz}$ のバンドパスフィルターをかけた波形を用いて検討してい ることから、本評価は HKD020 に合わせて $0.1 〜 3.0 \mathrm{~Hz}$ を対象とす る。また、観測記録とシミュレーションの包絡関数の振幅(式(24)) と 位相(式(25))をFig.12に示す。観測記録とシミュレーション結果を目 視により比較すると、震源に近く、破壊伝播の Forward 側に位置す る HKD020 のシミュレーションは、観測記録の波形に見られる5 秒 付近のパルスを再現している。水平成分の観測記録の包絡関数の振 幅に見られる $0.5 \mathrm{~Hz}$ 付近のピークや、0.1 $3 \mathrm{~Hz}$ において概小 $-45^{\circ}$
Table7 Comparison G OF for N51 and N54

\begin{tabular}{|c|c|c|c|c||}
\hline & \multicolumn{2}{|c|}{ N51 } & \multicolumn{2}{c|}{ N54 } \\
\cline { 2 - 5 } & Citak et al. & Kawabe & Citak et al. & Kawabe \\
\hline Phase GOF $_{\theta}$ & 4.62 & 1.59 & 8.94 & 9.30 \\
\hline Amp. GOF & 5.75 & 3.91 & 9.44 & 9.50 \\
\hline Total GOF & 5.31 & 2.01 & 9.05 & 9.26 \\
\hline
\end{tabular}

となっている位相を再現している。特に水平動は上下動よりも再現 性が良い。破壊伝播の Backward 側に位置する RMIH04 のシミュ レーションは、観測記録の波形の EW 成分に見られる 10 秒付近の パルスは再現されているが、他の成分の再現性は HKD020 より低 いと思われる。包絡関数の振幅は観測記録の $1 \mathrm{~Hz}$ 付近のピークの再 現性が低く過小評価気味となっており、位相も HKD020 ほど合っ ていない。

HKD020 と RMIH04 の観測記録に対するシミュレーションの適 合度をTable8に示す。HKD020 のE-GOF は、NS が Good、EW が Excellent、UD が Fair であり、水平動は観測記録との適合度が高い。 特に位相のE-GOF $F_{\theta}$ が Excellent で高い適合度を示しており、速度波 形のパルスの再現性の良さと整合する。E-GOF であり、振幅も再現性が良い。RMIH04 のE-GOF EW が Fair、UD が Poorである。水平動が上下動よりも適合度が高 い点は HKD020 と同じである。EW のE-GOF 良い評価であり、速度波形のパルスの再現性の良さと整合する。 $E-G O F_{A}$ は Fair または Poor であり、観測記録の再現性が低い。 HKD020 と RMIH04 は、前者の方が後者よりも 1 2 ランク適合度 が高く観測記録の再現性が良いと評価できる。震源近傍に位置する HKD020 は、地震波の散乱の影響をほとんど受けないため、SMGA を適切に調整すればシミュレーションが可能と元木ほか 5)は指摘し ている。

このように、波形の比較による定性的な評価と $E-G O F 、 E-G O F_{\theta}$ 、 $E-G O F_{A}$ を用いた定量的な評価は対応しており、指標を用いることで より定量的に観測記録との適合度を判断することができる。

5. まとめ

本研究では、波形の振幅と位相の両者を考慮できる $\mathrm{FDE}^{18)}$ につい 

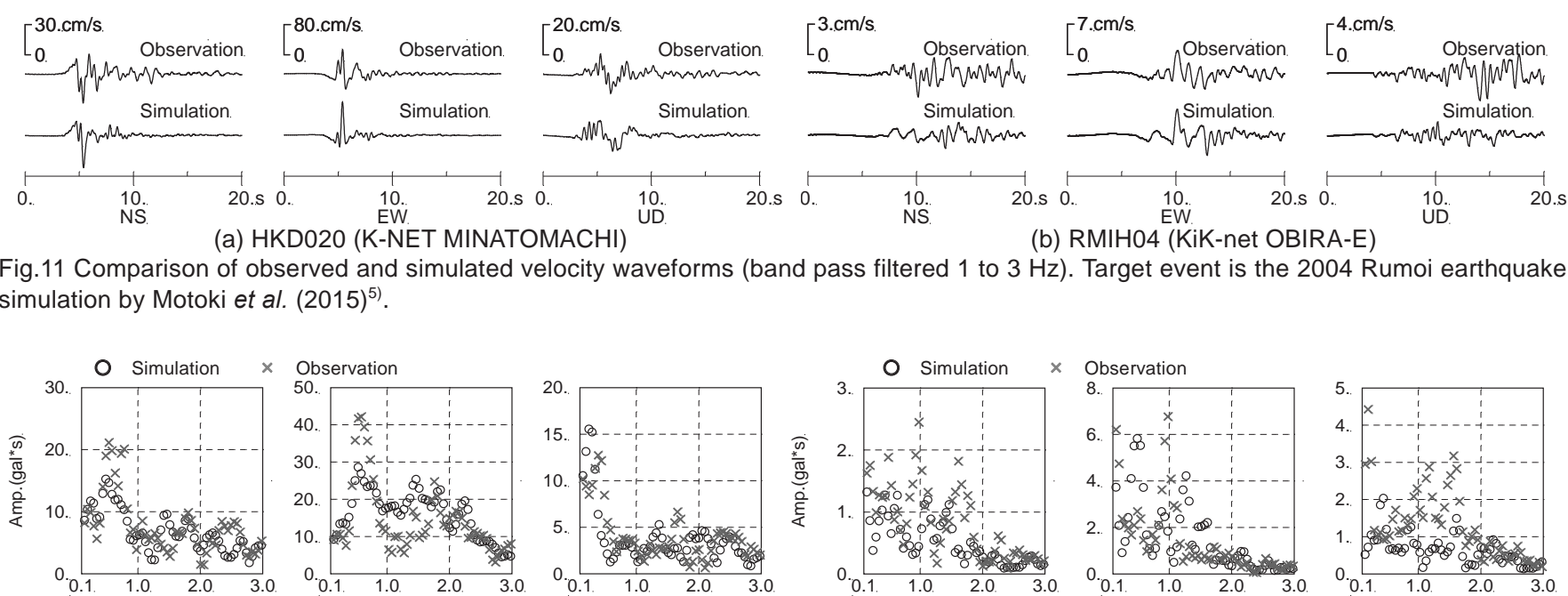

EW

$\begin{array}{lcl}10 . & 20.5 & 0 . \\ \text { (b) } & \text { RMIHO4 } & \text { EW } \\ \text { KiK-net OBIRA-E) }\end{array}$

Fig. 11 Comparison of observed and simulated velocity waveforms (band pass filtered 1 to $3 \mathrm{~Hz}$ ). Target event is the 2004 Rumoi earthquake simulation by Motoki et al. $(2015)^{5)}$.
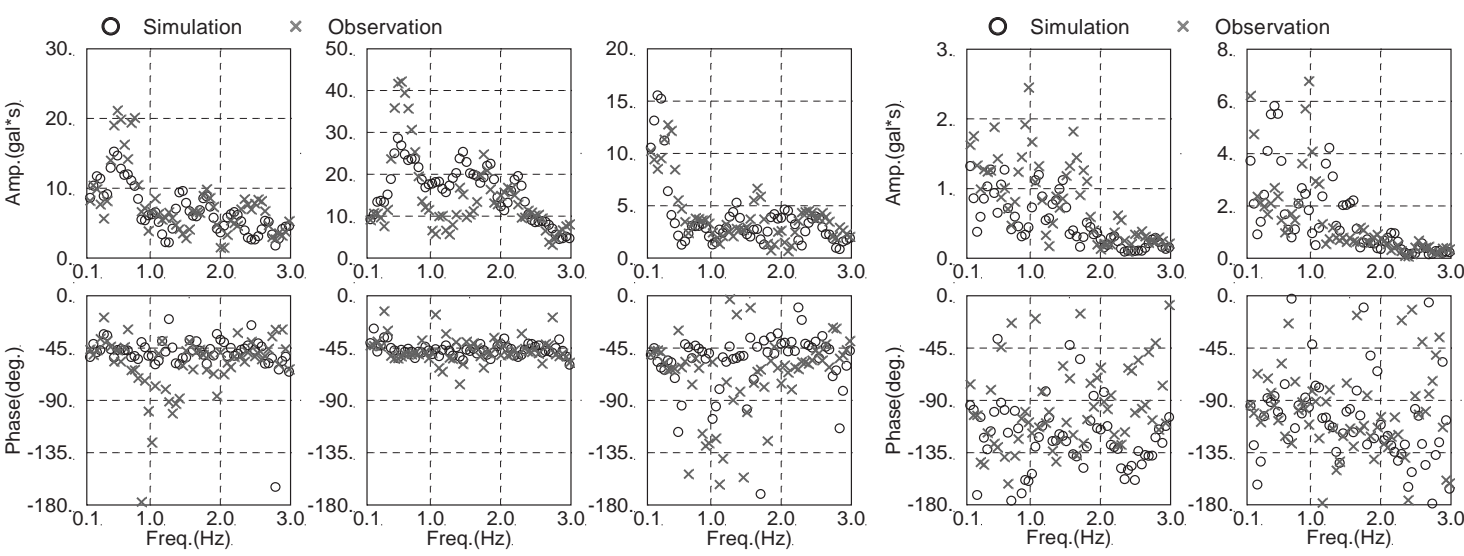

(a) HKD020 (K-NET MINATOMACHI)

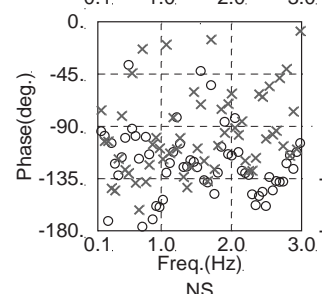

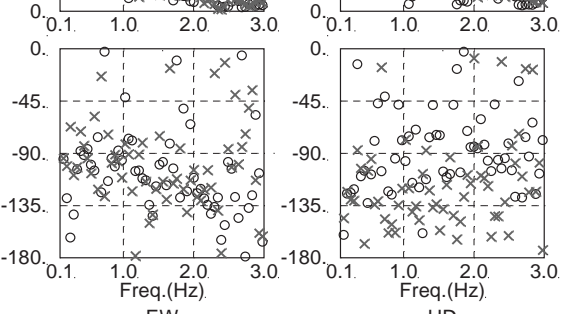

(b) RMIH04 (KiK-net OBIRA-E)

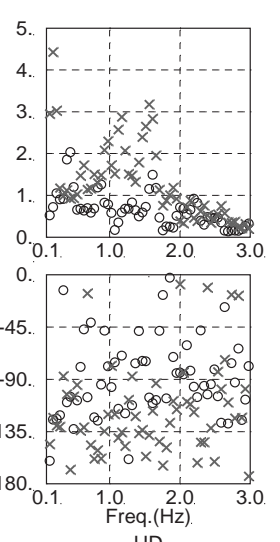

UD

Fig.12 Envelope function amplitude $\overline{A_{k}}$ (top, equation (24)) and phase $\overline{\Delta \theta_{k}}$ (bottom, equation (25)).

Table8 Comparison GOF for HKD020 and R MIH04

\begin{tabular}{|c|c|c|c|c|c|c|c|}
\hline & \multicolumn{3}{|c|}{ HKD020 } & \multicolumn{3}{|c|}{ RMIH04 } & \multirow[b]{2}{*}{ EXCEL } \\
\hline & NS & EW & UD & NS & EW & UD & \\
\hline Phase $\mathrm{E}-\mathrm{GOF}_{\theta}$ & 8.81 & 9.72 & 7.07 & 4.95 & 6.96 & 3.67 & GOOD \\
\hline Amp. E- $-\mathrm{GOF}_{\mathrm{A}}$ & 7.79 & 7.60 & 6.13 & 4.99 & 3.35 & 2.73 & FAIR \\
\hline Total E-GOF & 7.88 & 8.49 & 5.99 & 4.22 & 4.05 & 2.59 & POOR \\
\hline
\end{tabular}

て改良と高度化を行い、適合度評価に適用した。以下に得られた結 果をまとめる。

1) 既往指標のうち、振幅の指標は位相の誤差の影響を受けて適切 に誤差を評価できない場合があるため、そのような影響を受け ない改良指標を提案した。

2) 既往の位相と振幅の評価指標は1つの周波数のみに対する指標 であるため、幅を持った周波数帯域に対する位相と振幅の指標 $F D E_{\theta}$ と $F D E_{A}$ を提案した。 $F D E_{\theta}$ と $F D E_{A}$ は評価する周波数帯域の 中で振幅の大きな周波数の誤差に重みがかかる指標である。

3) これらの指標に対し、A nderson ${ }^{6)}$ 等の既往の指標と振幅に関寸 る評価が概补同じとなるよう4段階のランク [Excellent, Good, Fair, Poor]を設定した。これらの提案した指標が適切に適合度を 評価することができるかを、位相と振幅に誤差を与えた簡易な 模擬波形を用いて検証した。

4) 位相差分と波形の包絡形の関係を利用して、FDEを応用した波 形の包絡形の評価法を提案した。包絡形の評価には隣り合う周 波数の成分波の合成波の包絡関数を用い、その振幅と位相を評 価することとした。

5) 2章で提案した波形の適合度評価指標を、吉村ほか ${ }^{25}$ の強震動予 測手法に関するベンチマークテストのV erificationに用い、計算 波形同士の適合度を評価した。評価結果は吉村ほか25)で述べら
れている定性的な評価と一致しており、それらを定量的に評価 できる指標であることを示した。

6) 3章で提案した包絡形の適合度評価指標を、元木ほか シミュレーションのV alidationに用い、計算波形と観測記録の適 合度を評価した。評価結果は波形の比較による定性的な評価と 一致しており、それらを定量的に評価できる指標であることを 示した。

なお、複数の観測点を対象とする地震動シミュレーションにおい て本指標により面的に観測記録との適合度を評価することも可能で ある。多くの地点でEXCELENTPGOOD となった場合は、震源モデ ルや地下構造モデルなど解析全体の妥当性を示すことができる。 POORの地点がある場合は、それが広域で生じているか局所的かに 応じて、次のステップにおける震源モデルや特定の地域の地下構造 モデルの修正の判断に役立てることができる。

\section{謝辞}

防災科学技術研究所による強震観測網 K-NET と KiK -net のデータ を利用しました。工学院大学久田研究室 HP より強震動予測手法に 関するベンチマークテストのデータを利用しました。2 名の查読者 の方々から貴重なご意見を頂きました。ここに記して感謝致します。

\section{参考文献}

1) Hisada, Y ., M. Nagano, A. N ozu, and K. M iyakoshi: Benchmark tests for strong ground motion prediction methods: Case for theoretical methods (Part 1), AlJ J ournal of Technology and Design, V ol. 17, N o.35, pp. 43-48, 2011.2 (in J apanese) 久田嘉章, 永野正行, 野津厚, 宮腰研: 強震動予测手法に関寸るベンチマー クテスト：理論的手法の場合(その 1)，日本建築学会技術報告集，第 17 巻， 第 35 号, pp. 43-48, 2011.2

2) K ato, K., Y. Hisada, H. Kawabe, S. Ohno, A. N ozu, A. Nobata, A. M orikawa, and $Y$. Y amamoto: B enchmark tests for strong ground motion prediction methods: Case 
for stochastic Green's function method (Part 1), All J ournal of Technology and Design, V ol. 17, N o.35, pp. 49-54, 2011.2 (in J apanese)

加藤研一，久田嘉章，川辺秀憲，大野晋，野津厚，野畑有秀，森川淳，山本優: 強震動予測手法に関するベンチマークテスト: 統計的グリーン関数法の場合 (その 1)，日本建築学会技術報告集，第 17 巻，第 35 号, pp. 49-54, 2011.2

3) Y oshimura, C., M. Nagano, Y. Hisada, S. A oi, T. Hayakawa, S. O. Citak, S. $M$ atsushima, and $Y$. Onishi: Benchmark tests for strong ground motion prediction methods: case for numerical methods (part 1), AlJ Journal of Technology and Design, Vol. 17, N o.35, pp. 67-72, 2011.2 (in Japanese)

吉村智昭，永野正行，久田嘉章，青井真，早川崇， S. O. Citak，松島信一，大 西良広: 強震動予測手法に関するベンチマークテスト: 数值解析手法の場 合(その 1)，日本建築学会技術報告集，第 17 巻，第 35 号, pp. 67-72, 2011.2

4) K ato, K., Y. Hisada, S. M anabe, A. N ozu, A. N obata, A. M orikawa, S. O hno, and Y . Y amamoto: B enchmark tests for the Stochastic Green's F unction M ethod based on strong ground motions observed at the $2004 \mathrm{Kii}$-hanto-nanto-oki earthquake (M Jma 7.1), J ournal of J AEE (Special Issue), V ol. 16, No.3, pp.234-244, 2016.1 (in Japanese)

加藤研一, 久田嘉章, 眞鍋俊平, 野津厚, 野畑有秀, 森川淳, 大野晋，山本 優: 2004 年紀伊半島南東沖の地震(M JMA 7.1)の強震波形に基づく統計的グリ ーン関数法のベンチマークテスト，日本地震工学会論文集，第 16 巻，第 3 号(特集号), pp.234-244, 2016.1

5) M otoki, K., K. K ato, and A. Okazaki: Characteristics of strong motions near the source region of the 2004 Rumoi earthquake, J ournal of J AEE (Special Issue), Vol. 15, N 0.7, pp.72-89, 2015.9 (in J apanese)

元木健太郎，加藤研一，岡崎敦: 2004 年留萌支庁南部の地震の震源近傍にお ける地震動シミュレーション，日本地震工学会論文集，第 15 巻，第 7 号(特 集号), pp. 72-89, 2015.9

6) Anderson, J.G.: Quantitative measure of the goodness-of-fit of synthetic seismograms, in Proceedings of the 13th World Conference on Earthquake Engineering, Vancouver, B.C., Canada, Paper No. 243, 2004.8

7) Bielak, J., R. W. Graves, K. B. Olsen, R. Taborda, L. Ramirez-Guzman, S. M. Day, G. P. Ely, D. Roten, T. H. J ordan, P. J. M aechling, J. U rbanic, Y. Cui, and G. J uve: The ShakeO ut earthquake scenario: V erification of three simulation sets, $G$ eophys. J. Int., 180, pp. 375-404, 2010.1

8) Chaljub, E., P. M oczo, S. Tsuno, P.-Y. B ard, J. K ristek, M. Käser, M. Stupazzini, and M. K risteková: Quantitative comparison of four numerical predictions of $3 D$ ground motion in the Grenoble valley, France, Bull. Seismol. Soc. Am., V ol. 100, No. 4, pp. 1427-1455, 2010.8

9) Olsen, K. B. and J. E. M ayhew: Goodness-of-fit criteria for broadband synthetic seismograms, with application to the $2008 \mathrm{Mw} 5.4$ Chino Hills, California, earthquake, Seismol. Res. Lett., V ol. 81, N o. 5, pp. 715-723, 2010.9

10) Ramírez-Guzmán, L., O. S. Boyd, S. Hartzell, and R. A. Williams: Seismic velocity model of the central U nited States (V ersion 1): Description and simulation of the 18 A pril $2008 \mathrm{M} \mathrm{t}$. Carmel, Illinois, earthquake, Bull. Seismol. Soc. Am., Vol. 102, No. 6, pp. 2622-2645, 2012.12

11) D hakal, Y . P. and H. Y amanaka: 3-D Finite Difference Simulation of L ong-Period Ground M otions for the Performance A nalysis of two Subsurface $V$ elocity M odels of the Kanto Basin Using Moderate Magnitude Earthquakes, Joint Conf. Proceedings: 9th Intl. Conf. on U rban Earthq. Engg. \& 4th A sia Conf. on Earthq. Engg., M arch 6-8, Tokyo, Japan, paper ID 01-230, pp. 373-382. 2012.3

12) Dreger, D. S., G. C. B eroza, S. M. Day, C. A . Goulet, T. H. J ordan, P. A . Spudich, and J. P. Stewart: V alidation of the SCEC broadband platform V 14.3 simulation methods using pseudospectral acceleration data, Seismol. Res. Lett., V ol. 86, No. 1, pp. 39-47, 2015.1

13) Goulet, C. A., N. A. A brahamson, P. G. Somerville, and K. E. Wooddell: The SCEC B roadband Platform V alidation Exercise: M ethodology for Code $V$ alidation in the Context of Seismic-Hazard A nalyses, Seismol. Res. Lett., Vol.86, N o.1, pp. 17-26, 2015.1

14) M elgar, D., R. J. LeV eque, D. S. Dreger, and R. M. Allen: Kinematic rupture scenarios and synthetic displacement data: An example application to the Cascadia subduction zone, J. G eophys. Res. Solid Earth, V ol. 121, N o. 9, pp. 6658-6674, 2016.8

15) Kristeková, M., J. Kristek, P. Moczo, and S. M. Day: Misfit criteria for quantitative comparison of seismograms. Bull. Seism. Soc. Am., V ol. 96, No. 5, pp. 1836-1850, 2006.10

16) K risteková, M., J. K ristek, and P. M oczo: Time-frequency misfit and goodnessof-fit criteria for quantitative comparison of time signals, G eophys. J. Int., V ol. 178, pp. 813-825, 2009.3

17) Nakamura, T., H. Takenaka, T. Okamoto, and Y. Kaneda: FDM simulation of seismic wave propagation for an aftershock of the 2009 Suruga Bay earthquake: Effects of ocean-bottom topography and seawater layer, Bull. Seism. Soc. Am., V ol. 102, No. 6, pp. 2420-2435, 2012.12

18) Dragovich, J. J. and A. L epage: FDE index for goodness-of-fit between measured and calculated response signals, E arthquake Engng. Struct. D yn., V ol. 38, pp. 1751$1758,2009.9$

19) Lepage, A., M. W. Hopper, S. A. Delgado, and J. J. Dragovich: Best-fit models for nonlinear seismic response of reinforced concrete frames, Engineering Structures, Vol. 32, pp. 2931-2939, 2010.6

20) Rodrigues, H., H. Varum, A. A rêde, and A. Costa: Comparative efficiency analysis of different nonlinear modeling strategies to simulate the biaxial response of RC columns, Earthq. Eng. \& Eng. Vib., Vol. 11, N o. 4, pp. 553-566, 2012.12

21) Ohsaki, Y., R. I wasaki, I. Ohkawa, and T. M asao: A study on phase characteristics of earthquake motions and its applications, Proc, of 5th J apan Earthq. Engr. Symp., pp. 201-207, 1978. (in J apanese)

大崎順彦，岩崎良二，大川 出，政尾亨：地震波の位相特性とその応用に関 する研究, 第 5 回日本地震工学シンポジウム講演集, pp. 201-207, 1978.

22) Izumi, M., and H. Katsukura: A fundamental study on extraction of phaseinformation in earthquake motions, Journal of Structural and Construction Engineering (Transactions of AlJ ), N 0.327, pp. 20-26, 1983.5 (in Japanese) 和泉正哲, 勝倉裕: 地震動の位相情報に関する基礎的研究, 日本建築学会構 造系論文報告集，第 327 号, pp. 20-26, 1983.5

23) Katsukura, H., T. Watanabe, and M. Izumi: A study on the phase properties of seismic waves, Proc, of 5th J apan Earthq. Engr. Symp., pp. 209-216, 1978.

24) $Y$ amane, $T$. and $S$. Nagahashi: A study on a generation of simulated earthquake ground motion considering phase difference characteristics: Part 1 Theoretical background of the relationship between phase difference distribution and envelope characteristics, J ournal of Structural and Construction Engineering (Transactions of AlJ ), N 0.553, pp. 49-56, 2002.3 (in J apanese)

山根尚志，長橋純男：位相差分特性を考慮した設計用模擬地震動作成に関 する研究 その 1 位相差分分布と地震動経時特性の関係に関する理論的背 景，日本建築学会構造系論文集，第 553 号, pp. 49-56, 2002.3

25) Y oshimura, C., M. Nagano, Y. Hisada, S. A oi, A. I waki, T. Hayakawa, S. O. Citak, S. Matsushima, and H. Kawabe: Benchmark tests for strong ground motion prediction methods: case for numerical methods (part 3), AlJ J ournal of Technology and D esign, Vol. 19, No. 41, pp. 65-70, 2013.2 (in J apanese) 吉村智昭，永野正行，久田嘉章，青井真，岩城麻子，早川崇，S. O.Citak，松島信 一，川辺秀憲: 強震動予測手法に関するベンチマークテスト: 数值解析手法 の場合(その 3)，日本建築学会技術報告集，第 19 巻，第 41 号，pp. 65-70, 2013.2 


\section{THE GOODNESS-OF-FIT BETWEEN OBSERVED AND SIMULATED WAVES}

Modification of the frequency domain error and application to verification and validation

$$
\begin{aligned}
\text { Fumino SUZUKI }{ }^{* 1} \text {, Kenichi KATO }{ }^{* 2} \text { and Tetsushi WATANABE }{ }^{* 3} \\
{ }^{* 1} \text { Kobori Research Complex Inc., M.Eng. } \\
{ }^{* 2} \text { Senior General Manager, Kobori Research Complex Inc., Dr.Eng. } \\
{ }^{* 3} \text { Assist. General Manager, Kobori Research Complex Inc., Dr.Eng. }
\end{aligned}
$$

Verification and validation $(V \& V)$ are important the simulation of seismic waves. To objectively perform the $V \& V$, indexes to quantitatively evaluate the goodness of fit (GOF) between observed and simulated waves is needed. In this study, we proposed indexes of GOF considering both the amplitude and the phase of the waveform.

The main points of this paper are summarized as follows.

1) The indexes are originally derived from the frequency domain error (FDE) proposed by Dragovich and Lepage $(2009)^{18)}$. We modified the FDE to expand finite frequency bands.

2) We also newly propose the GOF of envelope of waveform based on the similar concept of FDE.

3) The indexes were correlate to four ranks from Excellent, Good, Fair, and Poor. These ranks are al most corresponding to the previous studies (A nderson (2004)6) etc.). We check the effectiveness of these indexes and their ranks by artificially generated waves.

4) We apply the proposed indexes to $V \& V$ of benchmark tests for strong ground motion prediction methods ( Yoshimura et al., 2013 ${ }^{25)}$ ), and strong motion simulations of the 2004 R umoi earthquake ( M otoki et al., 2015 ${ }^{5}$ ). We conclude that the indexes can quantitatively judge the GOF between observed and simulated waves. 